\title{
TIME TO ABOLISH THE RULE IN SEARLE $V$ WALLBANK FOR Negligence AND NuisanCe Claims
}

\section{ANTHONY GRAY*}

\begin{abstract}
In this article, the author suggests that the old common law rule denying that an owner of property owes a duty of care in respect of escaping animals should be abolished. After discussing the original English case in which this finding was made and the reasons for its creation, the author questions whether the principle remains coherent with other legal principles in tort, including the massive development of the common law of tort in recent years. He concludes that the rule is an anachronism and should be abandoned. If the reasoning for the decision were ever applicable to Australian conditions, it is not applicable any longer. The rule reflects an exception to a general principle of now universal acceptance, without justification. The Australian High Court should take the opportunity to abandon the rule, in favour of the general application of tort principles to resolve such disputes. The courts are an appropriate law reform body in this context.
\end{abstract}

\section{INTRODUCTION}

In this article, I will propose that, in line with most other jurisdictions in the common law world, the law of tort in Australia should not continue to recognise in any context the so-called rule in Searle $v$ Wallbank. ${ }^{1}$ The rule, applied recently by the Queensland Court of Appeal in Smith $v$ Williams, ${ }^{2}$ has the effect that a landowner has no legal obligation to fence their property so as to avoid animals (not known to be dangerous) straying from the property, and so causing danger to road users and others. The number of road accidents

\footnotetext{
* Senior Lecturer, University of Southern Queensland. Thanks to an anonymous referee for helpful comments on an earlier draft.

${ }^{1}$ [1947] AC 341, accepted by the High Court of Australia in State Government Insurance Commission v Trigwell (1979) 142 CLR 617.

${ }^{2}$ [2006] QCA 439 (Unreported, McMurdo P, Keane and Holmes JJA, 3 November 2006).
} 
involving animals is significant, with an NRMA review of 2007 comprehensive car insurance claims in New South Wales finding that 9000 collisions involving animals were recorded in that State last year, involving an estimated cost of $\$ 70$ million. $^{3}$

This issue is relevant to all jurisdictions, not just Queensland and the Northern Territory. In those jurisdictions, the need is more pressing, given that the rule has not been abrogated by statute in relation to negligence claims, as has occurred elsewhere. ${ }^{4}$ However, it is submitted that there is also a need for reform in other jurisdictions, because even where the rule has been abrogated by statute, in most cases the statutes in fact only abrogate the principle in relation to cases of negligence, ${ }^{5}$ leaving open the future possibility that the principle could still apply if the case were brought in nuisance. ${ }^{6}$ In fact, there is authority for treating the consequences of straying animals in nuisance rather than negligence, so the possibility is not merely fanciful. ${ }^{7}$ Mason $\mathrm{J}$ in State Government Insurance Commission v Trigwell

\footnotetext{
${ }^{3}$ NRMA Insurance, 'Roos a Road Risk for NSW Motorists' (Press Release, 29 May 2008) $<$ http://www.nrma.com.au/about-us/media-releases/20080529-a.shtml $>$ at 4 October 2008. Nationwide figures are not available, but there is nothing to suggest that these indicative rates of accidents and costs would not be replicated per capita in other states. The data does not distinguish between livestock and other animals.

${ }^{4}$ See Civil Law (Wrongs) Act 2002 (ACT) s 214; Animals Act 1977 (NSW) s 7(2)(b); Civil Liability Act 1936 (SA) s 18; Law of Animals Act 1962 (Tas) s 19; Wrongs Act 1958 (Vic) s 33; Highways (Liability for Straying Animals) Act 1983 (WA) s 3.

${ }^{5}$ For example, s 18 of the Civil Liability Act 1936 (SA) confines the abrogation of the rule to cases of negligence, and the Act specifically provides in s 18 that the abrogation does not apply to cases of nuisance. Section 19 of the Law of Animals Act 1962 (Tas) and s 33 of the Wrongs Act 1958 (Vic) confine the abrogation to cases of negligence, as does s 8 of the Animals Act 1971 (c 22) (England). Section 3 of the Highways (Liability for Straying Animals) Act 1983 (WA) does the same, and explicitly recognises that damage caused by straying animals might be actionable as an 'intentional act or omission'.

${ }^{6}$ This was alluded to by the Queensland Court of Appeal in its recent decision in Smith $v$ Williams [2006] QCA 439 (Unreported, McMurdo P, Keane and Holmes JJA, 3 November 2006). On the boundaries between negligence and (public) nuisance, see Margaret Fordham, 'The Roll of the Negligence Bandwagon: What Role for Public Nuisance?' (2003) 11 Tort Law Review 26. It is true that many claimants in this context would not have to rely on nuisance, because in many cases the facts would give them a remedy in negligence. However, it is submitted that there will be some cases where a fault-based principle will not provide the plaintiff with a remedy.

${ }^{7}$ In State Government Insurance Commission v Trigwell (1979) 142 CLR 617, 638, Mason J (with whom Gibbs and Stephen JJ agreed) acknowledged that a permanent or temporary removal of the whole or part of a highway from public use could be actionable as nuisance, citing cases such as Trevett $v$ Lee [1955] 1 All ER 406; Ellis v Banyard (1911) 106 LT 51; and Cunningham v Whelan (1918) 52 Ir LT 67. See also Philip Clarke, 'Liability for Animals on the Highway: Legislative Reform in the Commonwealth (1985) 34 International and Comparative Law Quarterly 786, 788-9 and J R Spencer, 'Public Nuisance - A Critical
} 
expressly acknowledged that the rule in Searle could apply to claims in nuisance, ${ }^{8}$ and this was recently accepted by the Queensland Court of Appeal in Smith. ${ }^{9}$

I will argue that the rule is anachronistic and, if it ever was justified by social conditions, is no longer justified, a fact that has been recognised by various law reform bodies and parliaments. Nor does the rule fit well into the framework of tort law as it currently stands in Australia, bearing in mind the growth of the negligence action and case law from Donoghue $v$ Stevenson ${ }^{10}$ to the present day.

In Part II of this article I will outline the rule and the reasons for its creation, and how the rule was subsequently accepted in Australia, and I will summarise the law reform bodies' responses to the rule. In Part III I will highlight what I consider to be the difficulties with the decision, including its coherence with other legal principles at the time. In Part IV I will note some recent developments in the law of tort in Australia in order to consider what they might suggest for the future of the rule, with a view to coherence of

Examination' (1989) 48 Cambridge Law Journal 55. It is true that in Brodie v Singleton Shire Council; Ghantous v Hawkesbury City Council (2001) 206 CLR 512, Gaudron, McHugh and Gummow JJ found, at 540, that 'the tort of public nuisance in highway cases has been subsumed by the law of negligence'. However, that case was concerned with the liability of highway authorities and it is unclear whether the comments were also intended to apply to the question of the liability of an owner of property adjoining the highway for stray stock. Hayne $J$ in the same case suggested (at 635) that it was now too late to abandon the concept of public nuisance as the joint reasons suggested. See further F H Newark, 'The Boundaries of Nuisance' (1949) 65 Law Quarterly Review 480; P H Winfield, 'Nuisance as a Tort' (1931) 4 Cambridge Law Journal 189.

${ }^{8}$ (1979) 142 CLR 617, 637: 'to hold that there is a liability in nuisance for injury caused by straying animals, despite the immunity otherwise conferred by the rule in Searle $v$ Wallbank, would do much to subvert the operation of the rule itself'. Of course, the advantage for the plaintiff in suing for nuisance is that they do not need to prove a failure by the defendant to take reasonable care in order to claim a remedy; as Lord Simonds stated in Read $v$ J Lyons and Co Ltd [1947] AC 156, 183: 'if a man commits a legal nuisance, it is no answer to his injured neighbour that he took the utmost care not to commit it. There the liability is strict'. The same point was accepted by Gaudron, McHugh and Gummow JJ in Brodie v Singleton Shire Council; Ghantous v Hawkesbury City Council (2001) 206 CLR 512, 569.

9 [2006] QCA 439 (Unreported, McMurdo P, Keane and Holmes JJA, 3 November 2006). In Smith the Court of Appeal found ( at [13]) that liability in nuisance could not arise from the same facts because the rule, as explained in Trigwell, was of general application in terms of all tortious liability. The Court left open the question whether the rule could apply to a case of a defendant who intentionally brought their animals onto the highway, bearing in mind the precedent Deen $v$ Davies [1935] 2 KB 282 (see [16]-[17]), though it is not clear to me why this would not be a case of nuisance, given that many nuisances are intentional and the Queensland Court of Appeal found that the rule in Searle $v$ Wallbank applied to nuisance claims.

${ }^{10}[1932]$ AC 562. 
principle. In Part V I will consider which body or bodies should be responsible for reform of the law, and, by analogy with other torts cases in which the High Court of Australia has been prepared to reform the law, whether the same conditions exist in relation to the Searle precedent.

\section{The Rule in Searle V Wallbank}

In Searle $v$ Wallbank, the plaintiff was seriously injured when he was struck by a horse that had escaped from the defendant's property. Evidence was led that the fence surrounding the defendant's property was dilapidated, and there were gaps through which an animal such as a horse might pass.

The House of Lords found that a landowner was under no duty of care to fence their property in order to avoid animals escaping. Apart from statements that '[o]bviously road users cannot expect to have roads kept clear of animals', ${ }^{11}$ reasons for the refusal to admit a duty of care in such circumstances included the facts that:

(a) various Acts of Parliament providing for the breakup of English manors did not include such an obligation. For example, the Inclosure Act of 1801 and the amending Inclosure Act of 1845 provided for the dividing up of land between lords and commoners. Both Acts provided power (to a commissioner or a valuer) to make and alter public roads, and provided that 'carriage roads so set out should be well and sufficiently fenced on both sides by such of the persons interested as the commissioner or the valuer should direct', ${ }^{12}$ as well as that the roads 'were to be repaired by the inhabitants after certificate by two justices of the peace that the roads had been sufficiently formed and completed'. ${ }^{13}$ There was, however, no provision for the upkeep of the fences. In Searle $v$ Wallbank Viscount Maugham took this lack of words to mean that there was no intention to impose such liability on landowners, ${ }^{14}$ noting that even at the time of the decision many roads were not enclosed by fences or hedges, and owners of neighbouring land could be under no obligation to provide such a barrier; ${ }^{15}$

\footnotetext{
${ }^{11}$ Searle v Wallbank [1947] AC 341, 351 (Viscount Maugham)(with whom Lords Uthwatt and Thankerton agreed).

${ }^{12}$ Ibid 348.

${ }^{13}$ Ibid 349.

${ }^{14}$ Ibid.

${ }^{15}$ Ibid.
} 
(b) no comparison could be made between the right of a land owner to sue in the event that another man's animals strayed onto his land, treading on his 'corn or damag[ing] his herbage', because this was a right based on trespass not applicable to a user of a highway; ${ }^{16}$

(c) the so-called duty of occupiers of enclosed land to users of an adjoining highway was not capable of intelligent definition ${ }^{17}$ - it was unclear whether it would apply to all roads, including 'green lanes or bridle paths', ${ }^{18}$ it was unclear how high the fence or hedge would need to be and whether the nature of the animals that the landowner owned was relevant to the question of whether the duty was owed. The problem could have arisen because a trespasser might have created a gap in a hedge to create a short cut, or someone else might have inadvertently left a gate open; ${ }^{19}$

(d) precedent had decided against a duty to fence, ${ }^{20}$

(e) roads that had been laid were largely there for the benefit of owners of adjacent land, including farmers, and should not be considered to introduce liability on the part of landowners adjacent to the roadway for such accidents; ${ }^{21}$

(f) road users had to expect that there might be animals on the road, and should themselves use due care for their safety, given this expectation; ${ }^{22}$

(g) accidents to road users arising from animals straying onto the roads were 'so far as one can judge practically non-existent', even with the growth in the speed of car travel $;^{23}$

(h) there was doubt about whether it should have been foreseen that a horse's mere presence on the highway would lead to an accident. ${ }^{24}$

\footnotetext{
${ }^{16}$ Ibid 350 (Viscount Maugham)(with whom Lords Uthwatt and Thankerton agreed); 356 (Lord Porter).

${ }^{17}$ Ibid 351 (Viscount Maugham)(with whom Lords Uthwatt and Thankerton agreed).

${ }^{18}$ Ibid 350 (Viscount Maugham).

${ }^{19}$ Ibid 351-352 (Viscount Maugham).

${ }^{20}$ Ibid 356 (Lord Porter), citing Hadwell v Righton [1907] 2 KB 345; Higgins v Searle (1909)

100 LT 280; Ellis v Banyard (1911)106 LT 51 and Jones v Lee (1911)106 LT 123.

${ }^{21}$ Ibid 351 (Viscount Maugham).

${ }^{22}$ Ibid 357 (Lord Porter); 361 (Lord du Parcq).

${ }^{23}$ Ibid 352-353 (Viscount Maugham).

${ }^{24}$ Ibid 354 (Lord Porter).
} 


\section{A Reception of the Rule into the Common Law of Australia}

There was some ambivalence expressed by Australian State courts about the decision in Searle $v$ Wallbank. ${ }^{25}$ It was not followed in some other countries, ${ }^{26}$ but a majority of the High Court of Australia accepted the decision in State Government Insurance Commission $v$ Trigwell. ${ }^{27}$ In Trigwell a motorist (Rooke) was driving at night along a main road. She collided with two sheep that were owned by the Kerins, owners of land adjoining the highway. As a result of that collision, Rooke's vehicle collided with a motor car being driven by Trigwell in the opposite direction. Rooke was killed and Trigwell and his family suffered personal injuries. Questions arose as to the liability of the Kerins for the accident. A majority of the High Court of Australia applied the rule in Searle $v$ Wallbank, and denied any liability on the part of the owners of the sheep.

Aspects of the majority's reasoning were based on reluctance to overturn established rules just because the conditions on which the original decision was based no longer applied. ${ }^{28}$ There was a belief that law reform of this

\footnotetext{
${ }^{25}$ The decision was not followed in Western Australia (Thompson v Nix [1976] WAR 141 (partly because of inconsistent legislation in that State)) or Tasmania (Jones v McIntyre [1973] Tas SR 1), and had a mixed reception in New South Wales (Kelly $v$ Sweeney [1975] 2 NSWLR 720).

${ }^{26}$ For example, in Canada (see Fleming v Atkinson [1959] SCR 513, in which the Court rejected the Searle decision because it depended on particulars of highway dedication in England that had no equivalent in Canada, and because traffic conditions had dramatically changed since it and the precedents on which the decision was based); Scotland (Gardiner $v$ Miller [1967] SLT 29); and the United States (Carpenter v Biedekapp (1945) 61 NYS 2d 419). The American Law Institute's Restatement (Third) Torts - Drafts (2005) § 21 provides for strict liability for the possessor of trespassing livestock, unless the harm was not foreseeable or state law provides contrary rules

${ }^{27}$ (1979) 142 CLR 617. See Max Atkinson, 'Trigwell in the High Court - Judicial Opinion v Legal Principle: A Case of Bad Law from Bad Philosophy’ (1980-1982) 9 Sydney Law Review 541.

${ }^{28}$ See, for example, the comments of Barwick CJ in State Government Insurance Commission $v$ Trigwell (1979) 142 CLR 617, 623 ('this court ... cannot alter the common law because the Court may think that changes in the society make or tend to make that declaration of the common law inappropriate to the times'), and Gibbs J at 627 ('a settled rule is not abrogated because the conditions in which it was formulated no longer exist'). Mason $J$ (with whom Aickin J agreed) was more equivocal, conceding (at 633) that 'if it should emerge that a specific common law rule was based on the existence of particular conditions or circumstances, whether social or economic, then in a simple or clear case the court may be justified in moulding the rule to meet the new conditions and circumstances. But there are very powerful reasons why the court should be reluctant to engage in such an exercise.'
} 
magnitude was a matter for the Parliament rather than the courts. ${ }^{29}$ The rule was accepted as part of the 'received law', on the assumption that Australia was a settled colony. ${ }^{30}$ Mason $\mathrm{J}$ rejected the suggestion that the ordinary principles of negligence should apply to this kind of factual situation. ${ }^{31}$

In dissent, Murphy $\mathrm{J}$ believed that ordinary principles of negligence should apply and that the immunity should no longer be recognised, noting that the exception worked unfairness, elevating the economic interests of graziers above the safety of road users. ${ }^{32}$ Murphy $\mathrm{J}$ criticised the reluctance of his fellow judges to change the law, recognising the longstanding tradition of precedent development, and gave the developments in the law of negligence as one example. ${ }^{33}$

While the parliaments of most States in Australia have long ago abrogated the doctrine in Searle $v$ Wallbank (mostly in relation to negligence claims only), ${ }^{34}$ the doctrine continues to be applied in Queensland and the Northern Territory to claims in negligence and nuisance. Most recently, in 2006, the Queensland Court of Appeal in Smith $v$ Williams applied the rule to deny compensation to a plaintiff injured by cattle that had strayed onto a highway from nearby property owned by the defendant. ${ }^{35}$ There has, however, been

\footnotetext{
${ }^{29}$ State Government Insurance Commission v Trigwell (1979) 142 CLR 617, 629 (Stephen J); 634 (Mason J).

${ }^{30}$ Ibid 622-3 (Barwick CJ); 625 (Gibbs J); 634 (Mason J) (with whom Stephen J agreed); 653 (Aickin J). This reflects acceptance of Blackstone's reasoning that 'if an uninhabited country be discovered and planted by British subjects, all the English laws then in being, which are the birthright of every subject, are immediately there in force ... such colonists carry with them only so much of the English law as is applicable to their own situation' (quoted in Cooper $v$ Stuart (1889) 14 App Cas 286, 292). However in Mabo v State of Queensland (No 2)(1992) 175 CLR 1, the High Court rejected the proposition that Australia was an uninhabited country, potentially undermining the application of Blackstone's principle, and the reception of English law.

${ }^{31}$ State Government Insurance Commission v Trigwell (1979) 142 CLR 617, 637.

${ }^{32}$ Ibid 648.

${ }^{33}$ Ibid 650-1 (citing Bracton (in De Legibus et Consuetudinibus Angliae vols 1-4, reprinted by G E Woodbine (ed) (1915-1942)) and Sir Francis Bacon (in The Advancement of Learning (1605)) as recognising that the growth of English law through judicial decisions was inevitable).

${ }^{34}$ See above $\mathrm{n} 4$.

35 [2006] QCA 439 (Unreported, McMurdo P, Keane and Holmes JJA, 3 November 2006). The Court of Appeal in this case did, however, (at [16]) suggest that a different result might eventuate if it were shown that the landowner knew his cattle would move onto the roadway. (Of course this would be a difficult matter on which to lead evidence).
} 
No 2

some tendency by Queensland courts to seek to confine the application of the rule. $^{36}$

\section{B Statutory Abrogation of the Rule}

The rule in Searle $v$ Wallbank has been abrogated by legislation in most Australian states. ${ }^{37}$ It has been abrogated by statute in the United Kingdom, ${ }^{38}$ and in other overseas jurisdictions. ${ }^{39}$ In several cases, these reforms were preceded by reports of law reform commissions. For example, in the United Kingdom a 1953 report stated that the rule needed to be modified to meet modern traffic conditions and that ordinary principles of negligence should apply. ${ }^{40}$ A 1967 report stated that the case for reform was overwhelming. ${ }^{41}$ These conclusions were mirrored in reports by law reform commissions in South Australia, ${ }^{42}$ New South Wales, ${ }^{43}$ New Zealand, ${ }^{44}$ Victoria $^{45}$ and Western Australia. ${ }^{46}$

${ }^{36}$ For example, it was not applied to a case where the defendant was an organiser of an agricultural show. The defendant's attempts there to rely on the rule to avoid liability for the escape of a horse were unsuccessful; the court applied the ordinary rules of negligence: Graham v Royal National Agricultural and Industry Assoc of Queensland [1989] 1 Qd R 624.

${ }^{37}$ See for example, Civil Law (Wrongs) Act 2002 (ACT) s 214; Animals Act 1977 (NSW) s 7(2)(b) (see Brown v Toohey (1994) 35 NSWLR 417 for application); Civil Liability Act 1936 (SA) s 18; Law of Animals Act 1962 (Tas) s 19; Wrongs Act 1958 (Vic) s 33; Highways (Liability for Straying Animals) Act 1983 (WA) s 3. Typical wording is provided by the Victorian provision, which states that the Act abolishes 'so much of the common law relating to liability for negligence as excludes or restricts the duty which a person might owe to others to take reasonable care to see that damage is not caused by animals straying onto a highway'(emphasis added). Some of these Acts deal also with the rules relating to animals known to be dangerous, but this issue is beyond the scope of this paper.

${ }^{38}$ Animals Act 1971(c 22) (England) s 8. See also Alec Samuels, 'Statutes: The Animals Act 1971' (1971) 34 Modern Law Review 550.

${ }^{39}$ See, for example, Animals Law Reform Act 1989 (NZ) s 5.

${ }^{40}$ United Kingdom, The Report of the Committee on the Law of Civil Liability for Damage Done by Animals, Cmnd. 8746 (1953); see for commentary Samuels, above n 38.

${ }^{41}$ See generally The Law Commission, Civil Liability for Animals, Law Commission Paper No 13 (1967). However, as noted above, it has been suggested that, given that in Searle there was some suggestion of liability in public nuisance, the fact that the legislation in all mentioned jurisdictions apart from New South Wales and the Australian Capital Territory abolishes Searle only as regards negligence allows the continued possibility of the application of the rule where the action is framed in nuisance: Clarke, above $\mathrm{n} 7,788$.

${ }^{42}$ Law Relating to Animals, Law Reform Committee Report No 7 (1969).

${ }^{43}$ New South Wales Law Reform Commission, Civil Liability for Animals, Report No 8 (1970).

${ }^{44}$ The Torts and General Law Reform Committee, Law Relating to Liability for Animals (1975).

${ }^{45}$ The Statute Law Revision Committee, The Law Relating to Animals on Highways (1978).

${ }^{46}$ The Law Reform Commission of Western Australia, Liability for Stock Straying on to the Highway, Report No 11(2) (1981). See also Thomson v Nix [1976] WAR 141, where the 
Given that, in most of the statutes that have abrogated the rule, the abrogation applies to cases of negligence, the current status of the rule in Australia can be summarised as follows:

- $\quad$ In New South Wales and the Australian Capital Territory the rule has been completely abolished for all tort claims;

- In Victoria, South Australia, Tasmania and Western Australia the rule has been abolished in relation only to negligence claims;

- In Queensland and the Northern Territory the rule continues to apply to both negligence and nuisance claims.

\section{Some Difficult Aspects of the Decision}

I highlight now some difficulties that I see with the rule.

\section{A Why is Cattle Trespass Actionable but not Injury on the Highway?}

A difficulty thrown up by the Searle decision is the very different treatment applied where a landowner's animals trespass on the land of another, compared with the situation where a land owner's animals venture onto a roadway. In the first case, the affected landowner has a remedy under trespass if they suffered damage, as Lord Porter recognised in Searle ${ }^{47}$ and as has been noted by law reform commissions. ${ }^{48}$ In the second case, the damaged party does not. Yet in many cases the damage that an animal can do to users of a road is of much greater consequence than the consequences of animals trespassing on another's land, which could amount at its slightest to the 'consumption of a few cauliflowers' as has been noted by the Queensland Law Reform Commission. ${ }^{49}$ It is submitted to be perverse that an action is allowed in the one case and not the other. In so saying, I accept that the

\footnotetext{
Supreme Court of Western Australia, taking its lead from a 1970 Law Reform Committee report, found the rule in Searle not to be applicable in that State. The Western Australia Law Reform Commission Report suggested (at [6.14]) several factors to be used in assessing questions of negligence in highway accidents, and suggested also that an upper limit of $\$ 500,000$ be placed on the amount of damages recoverable for such an accident ([6.19], [6.21]). The Queensland Law Reform Commission's recommendations for reform were not acted upon (see Queensland Law Reform Commission, Civil Liability for Animals, Working Paper No 18 (1977).

${ }^{47}$ [1947] AC 341, 356; see also 350 (Viscount Maugham).

${ }^{48}$ See, for example, Queensland Law Reform Commission, Civil Liability for Animals, Working Paper No 18 (1977) 7.

${ }^{49}$ Ibid.
} 
different rules protect different interests and historically have different origins.

Why does the law seem to protect the property right but not the right to travel safely on the road? One partial answer appears in the judgment of Windeyer J in Benning $v$ Wong of $1969,{ }^{50}$ where his Honour, in observing trends in liability law, noted that

[d]evelopments in the law of tort are towards a liability for personal harm done to persons who are neighbours in Lord Atkin's sense. They need not be persons having an interest in land in the neighbourhood. The movement of the common law is away from any preoccupation it may once have had with the protection of rights in land. ${ }^{51}$

I am not alone in pointing out this apparent anomaly in relation to cattle trespass actions. As Lord Greene MR stated in Hughes $v$ Williams:

The rule appears to be ill adapted to modern conditions. A farmer who allows his cow to stray through a gap in his hedge onto his neighbour's land, where it consumes a few cauliflowers, is liable in damages to his neighbour, but if, through a similar gap in the hedge, it strays on the road and causes the overturning of a motor omnibus, with death or injury to 30 or 40 people, he is under no liability at all. I scarcely think this is a satisfactory state of affairs in the twentieth century. If it should prove not to be open to the House of Lords to deal with the rule, the attention of the legislature might be directed to considering the whole position with a view to ensuring the safety of His Majesty's subjects when they are lawfully using the highway. ${ }^{52}$

\section{B Should Negligence Principles have been Applied?}

An immediate reaction upon reading the judgment in Searle is to ask why ordinary principles of negligence did not apply to the case. The House of Lords had settled upon a general principle of negligence liability involving the neighbour test in 1932 in Donoghue v Stevenson, ${ }^{53}$ yet most members of the House of Lords studiously ignored this development in a case decided 15 years later. It is true that the rapid growth of negligence did not begin until well after Searle, ${ }^{54}$ and the full significance of the Donoghue decision was not immediately obvious. Negligence was not recognised then as the

\footnotetext{
${ }^{50}$ (1969) 122 CLR 249.

${ }^{51}$ Ibid 319 (emphasis added).

52 [1943] KB 574, 576.

53 [1932] AC 562.

${ }^{54}$ Perhaps traceable to Anns v Merton LBC [1978] AC 728.
} 
universal principle it is today. It is, of course, much easier to see with the benefit of hindsight. Perhaps a category-based approach still appealed to some. At this time, negligence was in its infancy, and not the primary source of liability in tort. The famous passage by Lord Atkin reads as follows:

The rule that you are to love your neighbour becomes in law, you must not injure your neighbour; and the lawyer's question, Who is my neighbour? receives a restricted reply. You must take reasonable care to avoid acts or omissions which you can reasonably foresee would be likely to injure your neighbour. Who, then, in law is my neighbour? The answer seems to be persons who are so closely and directly affected by my act that I ought reasonably to have them in contemplation as being so affected when I am directing my mind to the acts or omissions which are called in question. ${ }^{55}$

Applying this test, it is difficult to understand why a person using a roadway adjoining a property is not the neighbour of the property owner, such that the owner owes a duty of care to such road users, which may, depending on the circumstances, involve a duty to fence the property. These road users can certainly be closely and directly affected by the property owner's actions or inactions, and they can reasonably foresee that if they don't take steps to control my animals, they may escape and thereby cause someone else injury.

One judge in Searle, Lord du Parcq, did consider the argument in negligence:

Counsel for the appellant submitted that, apart from any question of liability for injury caused by an animal known to its owner to be dangerous, an owner might be liable on the ground of negligence if he could be shown to have failed in his duty to take reasonable care. I agree that, subject to certain reservations, this proposition should be accepted. In the case of Fardon $v$ Harcourt-Rivington in this House, Lord Atkin used words which I would respectfully adopt. 'Quite apart,' he said, 'from the liability imposed upon the owner of animals or the person having control of them by reason of knowledge of their propensities, there is the ordinary duty of a person to take care either that his animal or his chattel is not put to such a use as is likely to injure his neighbour - the ordinary duty to take care in such cases put upon negligence.' This is not a novel principle. As early as 1676, an action on the case was brought successfully against a defendant who had set about breaking a horse in Lincoln Inn Fields, 'a place ... much frequented by the King's subjects and unapt for such purposes'.

\footnotetext{
${ }^{55}$ Donoghue v Stevenson [1932] AC 562, 580.

56 [1947] AC 341, 359. His Lordship went on (at 360) to add two qualifications - that generally liability in negligence could not be established 'merely by proof that a defendant failed to provide against the possibility that a tame animal of mild disposition' would 'do some dangerous act contrary to its ordinary nature', and that 'even if a defendant's omission to
} 
Again, in the decision in Trigwell, there is little recognition of the fact that most would find the Donoghue $v$ Stevenson neighbour test satisfied in the paradigm of a highway accident caused by stray animals, such that a duty of care would be owed. Mason J cited the above passage by Lord du Parcq, but in dismissive terms, stating:

With great respect to his Lordship [Lord du Parcq] I do not consider it correct to approach the liability of a defendant for injury caused by a straying animal on the footing that the general principles of negligence are applicable. The common law rule which confers immunity ... from such liability is an exception to the ordinary principles of negligence. And in the area in which the rule operates, it negates the existence of a duty of care. ${ }^{57}$

One should bear in mind that when the House of Lords was formulating the general concept of a duty of care in Donoghue, it did not refer to exceptions such as the one Mason J above claims to exist. The other judge to explicitly consider Donoghue was Murphy J (in dissent), who concluded that its general principle was applicable to this case. ${ }^{58}$

Atkinson makes this point about the judgments in Searle and Trigwell in regard to their general failure to apply Donoghue. He argues that

if we gave up the claim that the Lords could make the law whatever they liked, we could hardly avoid the conclusion that their reasoning is in substance per incuriam a principle they were required to respect. ${ }^{59}$

He states that, if the principle from Donoghue $v$ Stevenson 'commands anything like the respect its fame suggests, it ought to have played some role in the Searle $v$ Wallbank judgment. ${ }^{, 60}$ He also claims that the High Court's judgment, in ignoring the neighbour principle, is (arguably) an 'abnegation of responsibility'.61

One might observe in the development of the law of negligence in England in the $19^{\text {th }}$ and $20^{\text {th }}$ centuries a move away from a category-based approach to liability for negligence, and towards a more generalised concept of duty of

control or secure an animal is negligent, nothing done by the animal that is contrary to its ordinary nature can be regarded ... as directly caused by such negligence.'

${ }^{57}$ State Government Insurance Commission v Trigwell (1979) 142 CLR 617, 637.

${ }^{58}$ Ibid 653.

${ }^{59}$ Atkinson, above n 27, 547-8.

${ }^{60}$ Ibid 543.

${ }^{61}$ Ibid. 
care that would fall to be applied to a broad variety of situations. ${ }^{62}$ This is also consistent with a move away from the old forms of action to generalised procedures.

In the case of Home Office $v$ Dorset Yacht Co Ltd ${ }^{63}$ the majority, who found that a duty of care existed in the situation where human escapees caused damage to another's property, justified their conclusion on principles of control and supervision - that the defendant was in a position to control the escapees, combined with the foreseeability of harm to victims such as the plaintiff - and essentially equated control with responsibility. ${ }^{64}$ Parallel reasoning can be used when the case is one of the escape of animals from the defendant's property. These are animals that are owned and controlled by the defendant. The defendant chooses to have the animals on the property, and, as owner, the defendant uses the animals as he or she wishes. The owner is required to supervise the animals, and should be liable for their escape, if the escape constitutes a breach of duty of care on the owner's part. Just as it is foreseeable that those humans held against their will may try to escape ${ }^{65}$ and that young children will wander, ${ }^{66}$ so it is also foreseeable that animals will not respect property boundaries and also seek to wander, if given the opportunity. It is reasonably foreseeable that those in the immediate vicinity of any of these events might suffer injury as a consequence of the escape.

In the context of a cricket ball having 'escaped', the House of Lords, in the famous decision in Bolton $v$ Stone,${ }^{67}$ found that those in control of a cricket ground owed a duty of care to those on neighbouring property or those who might be using an adjoining highway. In the circumstances of that case, it was true that the House found no breach of the duty, bearing in mind factors such as the distance from the cricket pitch to the area outside the ground, the very low number of occasions when balls had been struck out of the ground, and the fact that a fence had been constructed seventeen feet above the level

\footnotetext{
${ }^{62}$ Compare, for example, the approach of the majority in Heaven $v$ Pender (1883) 11 QBD 503 with Donoghue v Stevenson [1932] AC 562.

${ }^{63}$ [1970] AC 1004.

${ }^{64}$ See, for example, the comments of Lord Morris of Borth-y-Gest in ibid 1035. Control and supervision were also emphasised in the case of Camarthenshire County Council v Lewis [1955] AC 549, together with the absence of any conflicting duties of care owed by the defendant to others. It is not suggested that, in the context of this article, conflicts between differing duties of care are an issue either.

${ }^{65}$ See, for example, Home Office v Dorset Yacht Co Ltd [1970] AC 1004, 1034 (Lord Morris of Borth-y-Gest).

${ }^{66}$ Carmarthenshire CC v Lewis [1955] AC 549, 563 (Lord Reid).

${ }^{67}$ [1951] AC 850; see also Miller v Jackson [1977] QB 966.
} 
of the pitch. As a result, the risk of injury from wayward cricket balls to those outside the ground was considered remote.

Having established that a duty of care might exist in relation to 'escaping' children or 'escaping' cricket balls, it seems consistent then that a duty of care might exist in relation to 'escaping' animals. As in Bolton, there would then need to be further discussion as to whether the duty of care had been breached, taking into account the specific circumstances of the case. ${ }^{68}$

\section{The High Court's Recent Pronouncements on Negligence AND NuISANCE PRINCIPLES}

It will now be argued that the current position in Queensland and the Northern Territory regarding highway liability of property owners on the basis of negligence, and in all jurisdictions except New South Wales and the Australian Capital Territory on the basis of nuisance, is out of step with trends in Australia in relation to negligence. Even in 1963 these trends were evident to some:

[T]he tendency of the law in recent times has been to lessen the immunities and privileges of landowners and occupiers and to increase their responsibilities to others for what happens on their land. To hold that the respondent had a duty to his neighbours to take reasonable care to prevent [a danger] ... spreading would be in accordance with modern concepts of a land occupier's obligations. ${ }^{69}$

These specific developments occur in the general light of the continuing relevance of the comments of Lord Atkin in Donoghue to negligence decisions of the High Court of Australia, as this court has moved back to first principles in negligence after earlier seeking to refine the neighbour principle. $^{70}$

\footnotetext{
${ }^{68}$ The statistics on the number of road accidents involving animals would be instructive, particularly in relation to that particular region, just as the likelihood of an accident occurring was judged in Bolton based on past experience at that cricket ground.

${ }^{69}$ Hargrave $v$ Goldman (1963) 110 CLR 40, 66-7 (where the High Court found that a landowner who allowed a fire to continue burning on his property for several days was liable in negligence and/or nuisance when the fire damaged a neighbouring property). This decision was confirmed by the Privy Council in Goldman v Hargrave (1966) 115 CLR 458.

${ }^{70}$ Speaking of Donoghue, Kirby J in Graham Barclay Oysters Pty Ltd v Ryan (2002) 211 CLR 317 (Barclay Oysters) commented (at 628) that '[p]erhaps this is the ultimate lesson for legal theory in the attempted conceptualisation of the law of negligence and the expression of a universal formula for the existence, or absence, of a legal duty of care on the part of one
} 


\section{A Subsumption of the Rule in Rylands v Fletcher into the General Law of Negligence}

In the landmark judgment of Burnie Port Authority $v$ General Jones Pty $L t d,^{71}$ the High Court of Australia ended the special principles that had applied to the liability of an occupier of premises for fire escaping from the premises, and rejected the Rylands $v$ Fletcher ${ }^{72}$ strict liability principle in respect of the escape of dangerous substances from premises.

The joint reasons in Burnie dismissed the above English common law rule (the ignis suus rule) in these terms:

Nor is there any reason in principle or policy for the preservation in this country of the special ignis suus rule formulated as appropriate to urban circumstances in medieval England. For one thing, that special rule was formulated before either the establishment of more general principles dealing with the escape of dangerous substances or the development of the modern law of negligence. For another, though fire is an exceptional hazard in Australia, contemporary conditions in this country have no real similarity to urban conditions in medieval England where the escape of domestic fire rivalled plague and war as a cause of general catastrophe. ${ }^{73}$

Analogous reasoning can be applied to the so-called rule in Searle. It was a special rule formulated before the development of the modern law of negligence. The case was decided after Donoghue but at a time when the full significance of the decision had not been appreciated. Just as a contrast was made between conditions in medieval England and those in Australia in relation to liability for fires, so a contrast can also be made in relation to liability for accidents on highways. Australian conditions have long involved vehicles travelling at high speeds across land, and there is no Australian equivalent of the large-scale 'break up of manors' referred to in Searle, by

\footnotetext{
person to another ... It may send those who pursue it around in never-ending circles that ultimately bring the traveller back to the very point at which the journey began.'. For example, Lord Atkin's formulation was applied expressly by members of the High Court in Annetts $v$ Australian Stations Pty Ltd (2002) 211 CLR 317, 330 (Gleeson CJ), 340-1 (Gaudron J), and 356 (McHugh J), as it was in Barclay Oysters at 599 (Gummow and Hayne JJ) and 627 (Kirby J), and in Gifford v Strang Patrick Stevedoring Pty Ltd (2003) 214 CLR 269, 276 (Gleeson CJ), 288 (McHugh J), 300 (Gummow and Kirby JJ), 304-5 (Hayne J) and 308-9 (Callinan J), and Sullivan v Moody (2001) 207 CLR 562, 577(Gleeson CJ, Gaudron, McHugh Hayne and Callinan JJ). See on this point Norman Katter, 'Who Then in Law is my Neighbour?' Reverting to First Principles in the High Court of Australia' (2004) 12 Tort Law Review 85.

${ }^{71}$ (1994) 179 CLR 520.

72 (1868) LR 3 HL 330.

73 (1994) 179 CLR 520, 534.
} 
No 2

virtue of which, owing to the dedication of adjoining landowners, roads were built. $^{74}$

In the Burnie judgment, the High Court also considered the old rule of strict liability contained in Blackburn J's judgment in Rylands $v$ Fletcher: ${ }^{75}$

The person who for his own purposes brings on his lands and collects and keeps there anything likely to do mischief if it escapes must keep it in at his peril, and if he does not do so, is prima facie answerable for all the damage which is the natural consequence of his escape. He can excuse himself by shewing that the escape was owing to the plaintiff's default; or perhaps that the escape was the consequence of vis major, or the act of God; but as nothing of this sort exists here, it is unnecessary to inquire what excuse would be sufficient.

These words had been applied broadly, ${ }^{76}$ and in Australia had allowed a plaintiff to recover even though they did not suffer damage to a property interest. $^{77}$ Nevertheless, the words had caused uncertainty, particularly over the meaning of what was 'naturally there'. 78

The joint reasons in Burnie subsumed Rylands and its progeny into the law of negligence, on the bases that virtually all of the cases decided on Rylands principles could be explained according to ordinary principles of negligence, and that the tort of negligence was on a much surer footing. The negligence principle was a general proposition suggested by recognised cases, and no obvious case could be stated where the liability was admitted to exist, but

\footnotetext{
${ }^{74}$ See the above discussion under Part A for the role that this factor played in the decision in Searle.

${ }^{75}$ Fletcher $v$ Rylands (1866) LR 1 Ex 265, 279-280 (Lord Blackburn), confirmed by the House of Lords in Rylands v Fletcher (1868) LR 3 HL 340.

${ }^{76}$ For example, on the facts of Rylands itself, water was held to be something 'likely to do mischief if it escapes' or 'dangerous': Burnie Port Authority v General Jones Pty Ltd (1994) 179 CLR 520, 538. The principle had also been expanded to include mere occupiers of land: see Burnie Port Authority v General Jones Pty Ltd (1994) 179 CLR 520, 536.

${ }^{77}$ See Windeyer J in Benning $v$ Wong (1969) 122 CLR 249, 320: 'A plaintiff can recover under [the Rylands principle] for personal injuries, or harm to his personal effects if, at the time when the escaping thing came upon him, he was in a place where he was lawfully entitled to be as a licensee, or a member of the public, such as on a highway (emphasis added) or in a public park'. In this way Rylands $v$ Fletcher liability could not be linked with liability in nuisance, as it could in England where a plaintiff in a Rylands case (at least initially) had to show interference with a property interest in order to obtain compensation: see, for example, the wording used by Blackburn J in Rylands v Fletcher (1866) LR 1 Ex 265, 280.

${ }^{78}$ See, for example, the discussion in Burnie Port Authority $v$ General Jones Pty Ltd (1994) 179 CLR 520, 537-9.
} 
was outside the proposition. ${ }^{79}$ The same could not be said for the Rylands principle and it was discarded.

The High Court of Australia here favoured broad principles over specific categories of case, principles which allowed outcomes to be reached that were expected and generally considered 'just'.

It is submitted that analogous reasoning applies to the so-called exceptional cases whereby landowners are not subject to liability for the consequences of their animals straying onto nearby roads. The exception applies to a specific category of case. However many cases in this category could be seen as appropriate for the application of ordinary conceptions of negligence. The High Court preference is for supportable rules of general application to a wide variety of circumstances, not specific narrow rules that might apply in a narrow category of case. The High Court therefore prefers to apply principles such as the negligence principle.

Further, in my view, a law immunising owners of land from liability in cases where straying stock cause injury is an example of an obvious case in which the liability must be admitted to possibly exist (or certainly a duty of care must be admitted to exist), yet the rule in Searle means that the case is not recognised as attracting a duty of care.

Given that Rylands is now part of the ordinary law of negligence in Australia, a development with which I agree, my argument is that ordinary negligence principles should be applied to the question of the liability of an owner of animals which escape and do damage, without exception or immunity. Even if the English route were taken, and Rylands were considered part of the law of nuisance, ${ }^{81}$ the position would be (in my view) that ordinary principles of nuisance would apply to resolve the case, again without exception or immunity.

\footnotetext{
${ }^{79}$ Ibid 541-2.

${ }^{80}$ This is the author's interpretation of the statement in the joint reasons: 'no obvious case can be stated in which the liability must be admitted to exist, and which yet is not within this proposition': Burnie Port Authority v General Jones Pty Ltd (1994) 179 CLR 520, 541-2.

${ }^{81}$ See Cambridge Water Co v Eastern Counties Leather Plc [1994] 2 AC 264. Public nuisance is considered below.
} 


\section{B Abolition of the Highway Immunity Rule}

In Brodie v Singleton; Ghantous v Hawkesbury City Council, ${ }^{82}$ the High Court abolished the immunity previously enjoyed by highway authorities in relation to non-feasance. A majority of the High Court rejected a rule, imported from England, that a highway authority could not be held legally liable for its failure to maintain infrastructure such as a bridge or a footpath.

A majority of the Court referred to difficulties with the principle, including the problem that the circumstances and assumptions upon which it depended never fully applied in Australia, and had anyway become much less relevant with time. ${ }^{83}$ Their Honours were referring to the fact that originally local village people were required to maintain the village's roadways. It was not thought right that these citizens should be held legally liable for failing to maintain these roadways. As these functions were eventually taken over by councils, the immunity once enjoyed by village people was inherited by councils, even though it was debatable whether the rationale for the rule was applicable in this context. Latterly, the immunity was justified in England on the basis that highway authorities were using public funds. ${ }^{84}$ In Australia, individual landowners had never owed an obligation to build or maintain roadways. $^{85}$ The responsibilities of councils for road works were created by statute. The Court noted that exceptions to the rule had created 'capricious' results, ${ }^{86}$ that the original position had been overturned in the country of its origin, ${ }^{87}$ and that a flood of claims had not eventuated against highway authorities there following abolition of the immunity. ${ }^{88}$

The Court, in its joint reasons in Brodie, also acknowledged that some cases of highway liability had been dealt with in public nuisance but, citing Burnie

82 (2001) 206 CLR 512. See for discussion Barbara McDonald, ' Immunities Under Attack: The Tort Liability of Highway Authorities and their Immunity from Liability for NonFeasance' (2000) 22 Sydney Law Review 411; Geoffrey Sawer, 'Non-Feasance Revisited' (1955) 18 Modern Law Review 541; Friedmann, 'Liability of Highway Authorities' (1951) 5 Res Judicatae 21; W Harrison Moore, 'Misfeasance and Non-Feasance in the Liability of Public Authorities' (1914) 30 Law Quarterly Review 276 (Part I) and 415 (Part II); Carolyn Coventry, 'You Had Better Watch Out: Liability of Public Authorities for Obvious Hazards in Footpaths' (2006) 14 Torts Law Journal 81.

${ }^{83}$ Brodie v Singleton Shire Council; Ghantous v Hawkesbury City Council (2001) 206 CLR 512, 543 (Gaudron, McHugh and Gummow JJ); 588 (Kirby J).

${ }^{84}$ The policy/operational distinction was also applicable (only) to public bodies.

${ }^{85}$ Brodie v Singleton Shire Council; Ghantous v Hawkesbury City Council (2001) 206 CLR $512,558,588$ (Kirby J).

${ }^{86}$ Ibid 549.

${ }^{87}$ Ibid 548.

${ }^{88}$ Ibid 549. 
Port Authority $v$ General Jones Pty Ltd, it found that the time had now come 'to treat public nuisance, in its application to the highway cases, "as absorbed by the principles of ordinary negligence", 89

This leaves open the question whether liability for escaping animals could be decided under principles of public nuisance. ${ }^{90}$ A 1535 case confirmed that an action in nuisance could arise if personal injury were sustained as a result of an obstruction in a public highway. ${ }^{91}$ However, given the High Court's subsumption of public nuisance, at least in highway cases (which were the most common public nuisance cases) to the law of negligence, it is unlikely that the High Court will halt the negligence 'bandwagon' any time soon. It might be argued that it is hard to see a rationale for subsuming public nuisance into negligence for highway cases, but not for others, given that the concepts of reasonableness and foreseeability also pervade public nuisance claims. $^{92}$ The House of Lords in Bolton, the escape case involving a cricket ball, accepted a concession from counsel that if the claim could not be made in negligence, it could also not be made in public nuisance. ${ }^{93}$

On the other hand, there are some cases of public nuisance where negligence was not argued or proved. The English court in Wandsworth London Borough Council v Railtrack plc upheld a claim in public nuisance without

${ }^{89}$ Brodie v Singleton Shire Council; Ghantous v Hawkesbury City Council (2001) 206 CLR 512,570 . Kirby $\mathrm{J}$ (at 589) put it in different words - that the highway immunity principle, which pre-dated the law of negligence, had been overtaken by profound developments in the tort of negligence. Again, it is not clear whether these sentiments are confined to the liability of highway authorities, or are also relevant to claims against the owner of land that abuts a highway. Hayne J (at 609) referred to an ancient English case where it was held that an action for nuisance could be maintained if personal injury were sustained as a result of an obstruction in a public highway. He concluded (at 635) that it was too late now to abandon the tort of public nuisance.

${ }_{90}$ This tort arose from a common law obligation, enforceable under the criminal law, to maintain the highways in parishes: Fordham, above n 6, '29.

${ }^{91}$ YB 27 Hen 8 Mich pl 10, in which Fitzherbert J stated that 'if a man make a trench across the highway, and I come riding that way by night, and I and my horse together fall in the trench so that I have great damage and inconvenience in that, I shall have an action against him who made the trench across the road because I am more damaged than any other man' (quoted in Brodie v Singleton Shire Council; Ghantous v Hawkesbury City Council (2001) 206 CLR 512, 609 (Hayne J)).

${ }_{92}$ Overseas Tankship (UK) Ltd v Miller Steamship Co Pty Ltd (No 2) [1967] 1 AC 617; Spencer, above n 7, 82('Where the public nuisance arises from something the defendant did on his property that endangered highway users he is only liable if he behaved unreasonably, and the same is true where the harm occurred because his trees grew over the highway or fell into it. In practice, this means that as the law stands he is only liable in the same cases in which he would also be liable in negligence.') See also Fordham, above n 6.

${ }^{93}$ Bolton v Stone [1951] AC 850, 860 (Lord Porter). 
making a specific finding as to negligence, because it viewed the claims as distinct: '[the defendant] is liable [in public nuisance], and there is no reason to approach the matter as though it were a claim in negligence or private nuisance.' 94

Hence, at this point, it is unclear in the straying animals context whether an action for public nuisance will arise in the absence of negligence in Australia. ${ }^{95}$ It is certainly possible on the current state of the authorities.

The judges in Brodie also made clear that the abolition of the immunity did not mean that highway authorities would always be held liable for nonfeasance; nor would the abolition require that all roads be brought into a perfect state of repair. What was required was a reasonable standard of care according to the accepted formulation of a standard of care decided by the Court in previous cases. ${ }^{96}$

As identified by some judges, there is an inherent logic binding liability for the maintenance of roadways and footpaths together with liability for the maintenance of fences dividing private property from roadways, ${ }^{97}$ or at least an obligation to take reasonable steps to prevent passers-by being injured by something escaping from property. In most cases, it was only when the roadway was built that the real danger to passers-by arose, because it was not until then that egress would be permitted in that area, other than by fellow landowners (who were already entitled to complain because of the long-

${ }^{94}$ [2002] 2 WLR 512, 520 (Kennedy LJ). His Honour went on (at 521-2) to dismiss one of the grounds of appeal, namely that the trial judge had failed to consider whether the defendant owed the plaintiff a duty of care, on the basis that the claim was one in public nuisance so duty of care was irrelevant (Chadwick LJ agreed with Kennedy LJ; Rougier LJ concurred). As indicated, Hayne $\mathrm{J}$ in Brodie thought that it was too late now to abandon the tort of public nuisance (see above $\mathrm{n}$ 89). It would require a re-interpretation of past decisions based on public nuisance where negligence was not argued or found, for example, where access to premises was interfered with (Taylor v City of Perth (1988) Aust Torts Reports 80-191), or views interrupted (Campbell v Paddington Corporation [1911] KB 869; Owen v O'Connor [1963] SR (NSW) 1051).

${ }^{95}$ Support for the proposition that liability in public nuisance is independent of liability in tort appears in the judgment of Murphy $\mathrm{J}$ (dissenting) in Cartwright $v$ McLaine and Long Pty Ltd (1979) 143 CLR 549, 571: 'In many cases, the law applies a strict liability because the solution suggested by the balancing of the social values involved is that any loss should fall on the defendant without proof of negligence.'

${ }^{96}$ Brodie v Singleton Shire Council; Ghantous v Hawkesbury City Council (2001) 206 CLR 512,540 . See, for example, the formulation of the standard of care by Mason J in Wyong Shire Council v Shirt (1980) 146 CLR 40, 47-8.

${ }^{97}$ An example appears in the judgment of Viscount Maugham in Searle v Wallbank [1947] AC 341, which discusses (at 348) the changes taking place in England requiring 'a good deal of roadmaking and fencing' (emphasis added). 
recognised tort of cattle trespass). It seems logical that a finding that a duty of care had been breached through a failure to maintain a roadway for which a highway authority has a responsibility could be equated with a breach of a duty of care through a failure to maintain a fence dividing private property from a roadway. ${ }^{98}$ In both Brodie and Searle, there was no absolute duty to provide a perfectly safe situation - merely the obligation to act reasonably in the circumstances. Just as a highway authority will not necessarily be held to have breached its duty of care merely because it fails to maintain a road in perfect condition, so too a landowner will not necessarily be held to have breached their duty of care merely because they fail to maintain a fence. However, the possibility should be accepted.

Also, in both cases the original reason for the immunity was financial. Given that roads were often repaired by locals, in Brodie the Court expressed concern at the financial impact that placing a legal responsibility for the consequences of non-maintenance on locals would have, ${ }^{99}$ just as the Court in Searle expressed concern at the financial impact that placing a legal responsibility on landowners for failure to fence (or take other reasonable precautions) would have. Many roads were not well frequented, and there might have been concerns about the ability to adequately limit the extent of liability owed in such situations.

As the availability of insurance has increased, these financial concerns have decreased. Nowadays local government authorities, often of large size, control roadways. They have the financial resources to meet some obligations regarding the condition of roadways under their control, such that an imposition of liability is no longer unreasonable. With the growth of the use of cars, and the rapid increase in typical driving speeds, users of roads have an expectation that roads will be reasonably safe to navigate. This expectation implies an obligation on the part of those who are in a position to control some aspects of driving conditions, including the state of road surfaces and signage, as well as on the part of those whose properties are nearby and who could create risks on the roads if their animals are not well

\footnotetext{
${ }^{98}$ In Brodie v Singleton Shire Council; Ghantous v Hawkesbury City Council (2001) 206 CLR 512, only Gleeson CJ (dissenting) expressly made the link between what was being considered in that case and the Searle precedent. Referring to comments by Mason J in Trigwell expressing reticence about overturning the longstanding English precedent although the conditions that brought the rule into existence had changed markedly, Gleeson CJ noted ( at 536) 'those considerations apply with equal force to the present case'.

${ }^{99}$ As noted in the joint reasons in Brodie, this obligation was enforced not by potential liability in damages, but upon criminal indictment: (2001) 206 CLR 512, 545 (Gaudron, McHugh and Gummow JJ), 607 (Hayne J).
} 
secured. The existence of a binding obligation is further implied by the number of accidents on roadways, the emotional costs that result, and the financial costs of treating the injured, etc. We best balance these costs against the cost of minimising the risk by applying principles of negligence to those responsible for road maintenance as well as to nearby property owners. Both have an obligation to make the road reasonably safe.

Both situations involve the failure of a person who has legal responsibility for something affecting public road safety to take appropriate action, in circumstances where road users might have a reasonable expectation that 1) the roads will be safe and 2) others will not act, or fail to act, in a way which might make the road more dangerous.

The question thus becomes the following: Having abolished highway immunity and so allowed the possibility that a highway authority could be held liable in negligence for failure to maintain a roadway, leading to dangerous conditions, should not the High Court by parity of reasoning abolish immunity for owners of land adjoining highways, recognising that such owners owe highway users a duty of care, and that their failure to maintain fences on their property, leading to dangerous conditions, may mean that they have breached their duty?

As for the impact of this proposed change in the law, it is submitted that the effects would not be particularly draconian, nor expose landowners to unacceptable risks of litigation. It is expected that a property owner would have access to public liability insurance as part of a general home and contents insurance policy, and that the public liability insurance would include cover for damage caused by animals escaping from the insured's premises, where the law would in some cases recognise a right of recovery for the victim. It is possible for landowners to obtain public liability insurance at relatively low cost. The loss would be borne by an insurer different from the insurer of the motor vehicle in which the victim was travelling. It would be the insurer of the premises from which the animal escaped (in circumstances justifying a claim) who would bear the loss. As a result, it is not expected that insurance premiums would be noticeably affected by the change in rule. Indeed, the Western Australian Law Reform Commission noted in its Report that in those jurisdictions where the rule had been abolished, public liability insurance premiums had not increased as a result. $^{100}$

${ }^{100}$ Law Reform Commission of Western Australia, above n 46, [6.16]. 
That Report also suggested that a cap be placed on the maximum amount for which damages could be awarded against the landowner in relation to such claims. ${ }^{101}$ This recommendation arose from a concern that landowners may not have sufficient insurance cover to pay any claim, and because of the potentially uncertain amount for which the landowner could be held responsible in relation to such an accident. ${ }^{102}$ However, given that public liability insurance policies for property owners commonly provide $\$ 10$ to $\$ 20$ million in cover for each claim, it is submitted that this would provide sufficient coverage such that the risk of the property owner having inadequate cover is low, particularly given the recent statutory reforms limiting the amount of damages available in respect of personal injury claims. As a result, the author is not presently in favour of placing a cap on the amount of damages to which the claimant may be entitled in relation to such claims. Further, to remove doubt, I am not suggesting that whether or not a defendant has insurance is relevant to questions of liability. ${ }^{103}$

\section{ASPECTS OF LAW REFORM}

\section{A Who is Responsible for Reform of the Law?}

An inevitable argument is whether it is for the courts or Parliament to reform the law in particular areas, and this theme runs through some of the major tort cases discussed in this article, such as Trigwell, Burnie, and Brodie. Of course, this is a matter about which reasonable minds might differ. There are clear advantages in reform of the law being carried out by both institutions, ${ }^{104}$ and no hard and fast answer can be given. ${ }^{105}$ The fact is that most jurisdictions have felt the strong need to overturn or limit the impact of the

\footnotetext{
${ }^{101}$ Ibid [6.19], [6.21].

${ }^{102}$ Ibid [6.18].

${ }^{103}$ See the discussion of this issue in Imbree $v$ McNeilly; McNeilly $v$ Imbree [2008] HCA 40.

${ }^{104}$ Some arguments appear in State Government Insurance Commission v Trigwell (1979) 142 CLR 617, 633-4 (Mason J, with whom Gibbs and Stephen JJ agreed) (in favour of Parliament), 649-652 (Murphy J) (in favour of the courts); in Burnie Port Authority v General Jones Pty Ltd (1994) 179 CLR 520, 592-4 (McHugh J) (in favour of Parliament), and in Brodie v Singleton Shire Council; Ghantous v Hawkesbury City Council (2001) 206 CLR 512, 593-4 (Kirby J) (in favour of the courts).

${ }^{105}$ Arguments that the courts should defer to Parliament might include the arguments that the rule is of such long standing that the courts generally are not equipped with the power or means to undertake the kind of review that should occur before important changes are made to a law, and that the courts cannot make law so as to deal comprehensively with all expected ramifications of a change in the law as Parliament can: see Barbara McDonald, 'Immunities Under Attack: The Tort Liability of Highway Authorities and their Immunity from Liability for Non-Feasance' (2000) 22 Sydney Law Review 411, 431-2.
} 
decision in Searle. This is not a vote of confidence in the capacity of the rule to meet community expectations. The reports of several law reform commissions have all favoured its abrogation. ${ }^{106}$

If we consider the aims of law reform given by Kirby $\mathrm{J}$ in Brodie as including 'the simplification of legal concepts, replacing categories with principles that will permit a more coherent and efficient application of the common law', then courts should, as Kirby J suggests,

reconsider the common law if, on analysis, that law appears to be out of harmony with altered social conditions. Or if it contains anachronistic categories that invite abolition or modification. Or if, effectively, it derogates unjustifiably from the principle of equality before the law. ${ }^{107}$

It is suggested that, on these tests, the rule in Searle $v$ Wallbank passes all the requirements for complete abolition. It creates a small category of circumstances in which ordinary concepts of negligence do not apply. The social conditions in which the rule might originally have been justified no longer exist. It clearly derogates from the principle of equality before the law, by treating one category of claimants, who have the misfortune to be involved in a collision with an animal, much less favourably than other claimants. Where the rule applies, a person whose cauliflowers were eaten by trespassing cattle has a right to claim more compensation than a person injured (perhaps seriously) by cattle on a highway. This is worse than absurd.

Of course the rule in Searle was created by the common law, so there is surely nothing wrong with the body charged with developing the common law from changing it. Radical changes have occurred for many years in the law of tort, all at the hands of judges. Tort law is largely a field that has been developed by the judges, rather than the Parliament. Of course, as Murphy J noted in Trigwell, we have long abandoned the fiction that the law never changes but is only discovered by the judges, ${ }^{108}$ and eminent jurists have for

\footnotetext{
${ }^{106}$ It is considered legitimate to consider the reports of law reform bodies, and changes in statute, when considering whether the existing common law should change.

107 (2001) 206 CLR 512, 594 (citing Esso Australia Resources Ltd v Federal Commissioner of Taxation (1999) 201 CLR 49, 88-9). Kirby J later said (at 603) that, while some immunities might be justified, they should be closely confined and fully justified by more than an appeal to legal history or precedent.

108 (1979) 142 CLR 617, 650. A comprehensive discussion of the arguments for reform as opposed to the maintenance of the status quo appears in McDonald, above $\mathrm{n}$ 105. The discussion occurs in the context of highway immunity, but the arguments are similar in relation to Searle.
} 
centuries recognised that the law should grow and develop through the course of decision-making, ${ }^{109}$ to reflect changes in society. As Lord Goff noted:

It is universally recognised that judicial development of the common law is inevitable. If it had never taken place, the common law would be the same now as it was in the reign of King Henry II; it is because of it that the common law is a living system of law, reacting to new events and new ideas, and so capable of providing the citizens of this country with a system of practical justice relevant to the times in which they live. ${ }^{110}$

\section{B Justifications Given by the High Court in Other Torts Contexts in Reforming the Law}

The High Court of Australia has undertaken radical reforms in the past 25 years in the area of tort. It may be helpful to focus on the rationale for some of these changes, to see whether the rationale is appropriate to the topic raised in this article. A general consideration in many of these cases has been that any changes that occur should not produce a situation of 'liability in an indeterminate amount for an indeterminate time to an indeterminate class'. 11 Another is the need for a coherent and comprehensive system of civil obligations, ${ }^{112}$ and there has been a (further) move away from category-based principles to those of a broader nature. ${ }^{113}$

For example, in the context of the subsumption of strict liability into the law of negligence in Burnie Port Authority $v$ General Jones Pty Ltd, ${ }^{114}$ the High Court gave several justifications for changing the law:

\footnotetext{
${ }^{109}$ See, for example, Sir Francis Bacon, The Advancement of Learning (1605) and Bracton, De Legibus et Consuetudinibus Angliae vols 1-4, G E Woodbine ed (1915-1942), cited in State Government Insurance Commission v Trigwell (1979) 142 CLR 617, 650 (Murphy J).

${ }^{110}$ Kleinwort Benson Ltd v Lincoln County Council [1999] 2 AC 349, 377.

${ }^{111}$ The words of Cardozo CJ in Ultramares Corporation v Touche, 174 NE 441, 444 (1931), referred to with approval by the High Court in cases such as Caltex Oil (Australia) Pty Ltd $v$ The Dredge Willemstad (1976) 136 CLR 529, 568 (Stephen J); Hill v Van Erp (1997) 188 CLR 159, 215 (McHugh J), 236 (Gummow J); and Perre v Apand Pty Ltd (1999) 198 CLR 180, 199 (Gaudron J).

112 'One consideration of significance when determining the existence of a duty of care is the provision already made, if any, by the general law in that regard. This is ... to determine whether there is a need consistently with the overall policy of the law to provide a coherent and comprehensive system of civil obligations, to supplement those established rules': Hill $v$ Van Erp (1997) 188 CLR 159, 223 (Gummow J).

${ }^{113}$ Perre v Apand Pty Ltd (1999) 198 CLR 180, 254: 'The emergence of a coherent body of precedents will be impeded, not assisted, by the imposition of a fixed system of categories' (Gummow J). See also 195 (Gaudron J) and 210 (McHugh J).

114 (1994) 179 CLR 520.
} 
(a) the existing special rule regarding liability for fires might have been appropriate for urban circumstances in medieval England, but was not appropriate to modern urban conditions in this country; ${ }^{115}$

(b) the past rule regarding strict liability was difficult to apply, leading to uncertainty in approach, meaning that the rule led to disunity and disparity within the individual category, rather than the unification of past cases into a coherent principle, as evidenced in the Donoghue $v$ Stevenson development; ${ }^{116}$

(c) some of the distinctions on which the rule was based were essentially arbitrary. ${ }^{117}$

Further, in articulating the rule in such cases, the joint reasons for judgment referred to concepts of 'control' and 'vulnerability' in establishing that a duty of care existed. In the Rylands-type cases one party to the relevant relationship was a person in control of premises who had used their control to introduce something dangerous onto the premises. ${ }^{118}$ The other party to that relationship was a person outside the premises and without control over what occurred therein, whose person or property was thus exposed to a foreseeable risk or danger. The person outside was thus in a position of special vulnerability and dependence, particularly where reasonable precautions were not taken by the other in relation to the premises. The outsider depended on the person in control of the premises to ensure that reasonable precautions were in fact taken. Commonly, the outsider lacked the right or opportunity to exercise control over, or even to know, what the other party had on the premises. The person in control thus assumed a particular responsibility for the safety of the other. ${ }^{119}$ Concepts of 'control' and 'vulnerability' have been applied in subsequent High Court judgments in assessing whether or not a duty of care might be owed in particular cases, including cases of purely economic loss. ${ }^{120}$

It is argued that the above justifications for reform of the law are also applicable in the context of the rule in Searle $v$ Wallbank. In terms of (a) above, the historical justifications given in Searle for the position reached in England were never applicable in Australia. Our statutes never provided for the break-up of manors or estates, and the law never required owners of land

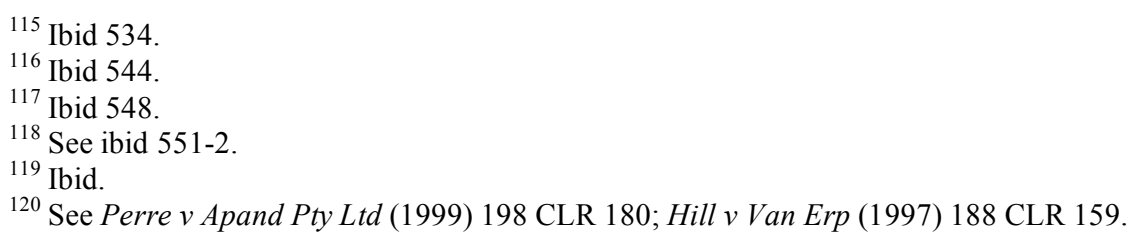


to contribute to the costs of maintaining roads abutting their property. As a result, it is not relevant to consider in Australia, as Viscount Maugham did in Searle, what the intention of the Acts providing for subdivision of property might be. ${ }^{121}$ Furthermore, road conditions have changed markedly over the centuries, ${ }^{122}$ with much faster vehicles, many more roads, and a massive increase in the traffic on roadways. Roadways are now commonly multi-lane, busy thoroughfares, not sleepy country lanes. If it ever was correct, it surely cannot be right now to say that road accidents involving animals are 'exceedingly rare', as Viscount Maugham claimed in Searle. ${ }^{123}$ Statistics presented by the NRMA recently, and referred to in the Western Australian Law Reform Commission's report on this issue, tell a different story, at least in the Australian context.

I have referred earlier in the article to the reasoning of the House of Lords in Searle. ${ }^{124}$ Apart from the argument as to the intention of the legislation providing for the break-up of manors, other rationales for the decision focused on the alleged inability of the courts to intelligently define 1) the scope of any duty owed by the property owner, 2) the difference in result if the stray animals caused damage to another's property rather than personal injury, and 3) what road users could expect on their roads.

In response to the line of reasoning in Searle that 'road users had to expect animals on the road', if this were ever correct, it is surely not correct now, given the industrialisation and globalisation of our economy and the recognition that agriculture is just one of our industries. Though it is an important industry, it is not so dominant as to feed an expectation that animals will be on roads. In addition, and despite the popular perception of Australia overseas, Australia is one of the most highly urbanised countries in the world, ${ }^{125}$ surely reducing (at the very least) the expectation that there will be animals on the road. These factual differences might suggest that the rule should not apply in Australia.

\footnotetext{
${ }^{121}$ [1947] AC 341, 349.

122 Noted by members of the High Court in State Government Insurance Commission $v$ Trigwell (1979) 142 CLR 617, 627 (Gibbs CJ), 634 (Mason J), and 646 (Murphy J).

123 [1947] AC 341, 353.

${ }^{124}$ See the discussion above under Part A.

125 'Australia became increasingly urbanised in the decade to 2006 ... [I]n 2006, two thirds of Australia's 21 million residents lived in major cities': Australian Bureau of Statistics, Australian Social Trends, Cat No $4102.0 \quad$ (2008) $<$ http://www.abs.gov.au/AUSSTATS/abs@.nsf/Lookup/4102.0Chapter3002008> at 7 October 2008.
} 
It is not just factual differences and changes that might call into question the applicability of the Searle reasoning in Australia. There have also been important changes in torts law since that time, not least the incredible growth of negligence at the expense of other torts, and the development and general acceptance of the Donoghue neighbourhood principle. These developments serve to make the comments in Searle - to the effect that a duty of occupiers of enclosed lands to users of an adjoining highway was not capable of intelligent definition - an anachronism today. Similarly, the allowance of a claim in trespass for stray cattle, yet not in negligence or any other tort, demonstrates a prominence given to torts other than negligence that we do not see in today's tort landscape. Given the exponential growth in the kinds of circumstances in which we now find a duty of care to be owed on the Donoghue test, comments such as 'I doubt whether it should have been foreseen that a horse's mere presence on the highway would lead to an accident ${ }^{126}$ seem anomalous. It is hard to conceive that they would or should be applicable in the very different circumstances today.

In support of the claim that a duty of care by a landowner to a user of a nearby road would be 'incapable of intelligent definition', Viscount Maugham referred to a number of alleged difficulties: how to draw a distinction between green lanes and bridle roads, how high the hedges or fences would need to be, whether the nature of the animals on the property was relevant, whether the gaps in hedges were caused by trespassers, or whether gates had been inadvertently left open. ${ }^{127}$

In today's system, these concerns are of little relevance in the framing of appropriate legal rules. In my view, one of the advantages of the generalised conception of negligence to which we now adhere is that it is flexible enough to take these kinds of variables into account. A duty of care is not an absolute duty to provide safety, but a requirement to take reasonable steps to provide safety. It is submitted that all of the factors mentioned above would be relevant in assessing whether the landowner had met his obligation to take reasonable care. If, for example, the landowner was keeping hens, the obligation to take reasonable care might not require a fence. However if they were keeping horses, the obligation would almost certainly require a fence. If a gate had inadvertently been left open by a visitor on the morning of the accident, and as a result an animal had escaped and caused an accident, it may well be that the landowner would be found not to have breached their duty of care. The volume of traffic that used the road would of course be

${ }^{126}$ Searle v Wallbank [1947] AC 341, 354 (Lord Porter).

${ }^{127}$ Ibid 351-2. 
relevant. All things being equal, the busier the roadway nearby, the more that might be expected of the property owner by way of reducing the risk of escaping animals.

In relation to (b) above, the effect of the rule is to create a special category of case, where no liability applies, and from which the application of the ordinary rules of negligence is excluded. Yet the High Court has rallied against special rules and exceptions, subsuming adventurous principles in tort into existing, more accepted principles ${ }^{128}$ and removing the categorisation of entrants as a basis for differential duties of care. It has simplified occupiers' liability to bring it into line with the general negligence standard, ${ }^{129}$ abandoned Rylands-style strict liability ${ }^{130}$ and abolished the special category for highway authorities. ${ }^{131}$ Yet, while these developments have simplified the law of tort and broken down barriers and categories in favour of general principles, Trigwell and its parent Searle have so far miraculously bucked the trend, and become increasingly isolated from the mainstream of tort law in Australia as applied in the $21^{\text {st }}$ century.

In relation to (c) above, if the High Court was not impressed with the arbitrariness of the application of the Rylands rule, it surely cannot be any more impressed with the arbitrariness involved in holding that, if a landowner carelessly allows his or her stock to roam free, liability attaches for damage to any crops the animal might eat, yet not for any personal injury the animal might cause to users of the nearby roadway.

In considering tort reform, the High Court has expressed concerns about the possibility of indeterminate liability attaching for an indeterminate time to an indeterminate class of persons. ${ }^{132}$ This concern may be most appropriate in cases of purely economic loss, and surely would not be justified in the present context. Liability would be determinate - you are liable as a property owner if you carelessly allow your animal to stray from your property, if it ventures onto a nearby road and causes injury to a user of that road. Liability would exist for a determinate time (ie for as long as the person owns the

\footnotetext{
${ }^{128}$ Northern Territory of Australia v Mengel (1995) 185 CLR 307, in which the High Court overruled the decision in Beaudesert Shire Council v Smith (1966) 120 CLR 145 which had suggested a separate action for loss arising from the inevitable consequence of the unlawful, intentional and positive acts of another.

${ }^{129}$ Australian Safeway Stores Proprietary Limited v Zaluzna (1987) 162 CLR 479.

${ }^{130}$ Burnie Port Authority v General Jones Pty Ltd (1994) 179 CLR 520.

${ }^{131}$ Brodie v Singleton Shire Council; Ghantous v Hawkesbury City Council (2001) 206 CLR 512.

${ }^{132}$ See above n 111.
} 
land) and it would be confined to a determinate class - those who use roads in the vicinity of the property.

In the language of 'control' and 'vulnerability', the owner of the animal controls them, and is in a position to take reasonable steps to restrain their animals, for example by appropriate fencing. The victim is not in control of the premises, and is in a vulnerable position because they cannot know the magnitude of the risk they take by using the road, or the probability that injury will occur from an escaped animal. They depend (or should be able to depend) on the owner of the animal to ensure that reasonable steps are taken to control the animal.

\section{CONCLUSION}

The rule in Searle $v$ Wallbank $^{133}$ must be completely abandoned. It should not apply to claims in negligence or to claims for public nuisance resulting from animals being on a public way, to the extent that these remain a possibility. A person injured in such circumstances has the right to compensation if they can make out their claim on the basis of ordinary principles of negligence, or principles of public nuisance.

Such a development would be consistent with trends in tort law in the past 80 years, particularly the past 20 in Australia. It would reflect the fundamental importance and dominance of the duty of care concept espoused in Donoghue $v$ Stevenson, ${ }^{134}$ and would be consistent with the High Court's rejection of immunity for non-feasance by highway authorities, and the High Court's insistence that past Rylands $v$ Fletcher-type claims ${ }^{135}$ should also be governed by the law of negligence. It would serve to improve the coherency of the principles on which we judge human behaviour for wrongs. It would reflect the radically different social conditions and expectations of members of society that exist today, compared with the distant past.

\footnotetext{
133 [1947] AC 341.

134 [1932] AC 562.

135 (1868) LR 3 HL 330.
} 